\title{
SISTEM PENDUKUNG KEPUTUSAN UNTUK DETEKSI DINI RISIKO PENYAKIT STROKE MENGGUNAKAN LEARNING VECTOR QUANTIZATION
}

\author{
(Decision Support System For Early Detection Of Stroke Disease Risk Using \\ Learning Vector Quantization) \\ Sugarwanto Atmaja \\ Prodi. Teknik Informatika, Fakultas Teknik, Universitas Muhammadiyah Sidoarjo \\ J1. Raya Gelam 250 Candi Sidoarjo \\ Email: Sugarwanto@gmail.com
}

\begin{abstract}
Stroke is any sudden neurologic disorder that occurs as a result of restriction or cessation of blood flow through brain arteries supply system. Stroke is the leading cause of death in Indonesia. Services pre-stroke is early detection activities, discovery and monitoring of risk factors for stroke in healthy individuals and at-risk communities that can be performed by physicians, nurses and health workers. Based on the results of the study said that when control stroke risk factors to do with the approach would reduce the number of defects by $60-90 \%$. Works doctor for diagnosis process is not easy because of the many risk factors vary and affect each other, for example Low Density Lipoprotein cholesterol can lead to heart disease can also affect blood pressure, gender can affect the value of uric acid, uric acid can also influence blood pressure and sugar levels can affect blood pressure. Classification method is one solution that is deemed able to handle the process of classifying the status of early detection of the risk of stroke. Mechanical classification using Learning Vector Quantization (LVQ) has excess generating an error value is smaller than other artificial neural networks. Based on the results of research and discussion conducted, algorithms LVQ can recognize patterns and are able to predict the status of early risk of stroke using a variable blood pressure, blood sugar, total cholesterol, Low Density Lipoprotein, age, gender, gout, Blood Urea Nitrogen and creatinine with a total value of up to $82 \%$ accuracy.
\end{abstract}

Keyword : Stroke, Classification, Learning Vector Quantization.

\section{PENDAHULUAN}

Stroke adalah setiap gangguan neurologik mendadak yang terjadi akibat pembatasan atau terhentinya aliran darah melalui sistem suplai arteri otak (Arifianto et al, 2014). Stroke merupakan penyebab kematian terbanyak di Indonesia. Hasil Riset Kesehatan Dasar (Reskesdas) Kemenkes RI tahun 2013 menunjukkan peningkatan prevalensi stroke di Indonesia dari 8,3 per mil pada tahun 2007 menjadi 12,1 per mil pada tahun 2013. Sebagian dari pasien yang mengalami stroke akan berakhir dengan kecacatan. Berdasarkan beberapa penelitian didapatkan tingkat kecacatan stroke mencapai 65\% (Kementerian Kesehatan Republik Indonesia, 2014).

Kebanyakan orang tidak mengetahui gejala-gejala stroke karena gejala-gejalanya kemungkinan bervariasi bergantung pada penyebabnya, akibat pengentalan darah atau perdarahan serta luas kerusakan area otak juga memengaruhi gejala. Gejala stroke bisa memburuk dalam hitungan menit, jam dan hari. Jika beberapa stroke ringan terjadi berulang seiring waktu, pasien kemungkinan mengalami perubahan jalan, keseimbangan, kemampuan berpikir atau perilaku secara bertahap (Media Indonesia, 2009; Sholeh, A.F. 2012). Saat ini bukan hanya gejala kelemahan tubuh saja yang menjadi fokus utama tetapi bisa saja terkena gangguan pada fungsi kognitif seperti lupa mendadak, gelap satu mata, pusing, bicara pelo mendadak, gangguan menelan, kesemutan seluruh badan mendadak dan gangguan keseimbangan mendadak. Stroke dapat menyebabkan gangguan baik fisik maupun emosional seseorang (Clinisindo Putra Perkasa, 2011; Sholeh, A.F. 2012). Dalam domain risiko serangan stroke, tekanan darah, umur, jenis kelamin, kolesterol dan riwayat diabetes merupakan faktor risiko utama yang memengaruhi risiko penyakit stroke (Yastroki, 2011; Sholeh, A.F. 2012).

Dari pendapat para ahli dapat diambil kesimpulan bahwa risiko terkena stroke yang mematikan dapat dicegah dengan mengenali gejalanya sedini mungkin dan untuk mendiagnosa dini penyakit stroke mempunyai beberapa faktor risiko utama seperti tekanan darah, jenis kelamin, umur, kolesterol serta riwayat diabetes. Bagi para ahli terkadang merupakan hal yang tidak mudah, karena banyaknya faktor risiko yang beragam dan saling memengaruhi. Dari permasalahan yang ada nantinya akan dibuat sebuah sistem pendukung keputusan yang dapat membantu para ahli untuk mendiagnosa dini risiko penyakit stroke. 
Sistem pendukung keputusan dengan metode klasifikasi merupakan salah satu solusi yang dirasa mampu menangani proses pengklasifikasi status deteksi dini risiko penyakit stroke. Teknik klasifikasi menggunakan metode Learning Vector Quantization (LVQ) memiliki kelebihan menghasilkan nilai error lebih kecil dibandingkan jaringan syaraf tiruan lainnya seperti backpropagation, model yang dihasilkan metode LVQ dapat diperbaharui secara bertahap, selain itu metode LVQ dikenal lebih efektif dari sisi sensitivitas, spesifisitas, akurasi, dan beban komputasi dalam proses klasifikasi dibandingkan dengan metode backpropagation (Dharmawan, D.A. 2014).

\section{II.TINJAUAN PUSTAKA}

\section{A. Pengendalian Stroke}

Untuk menurunkan angka kesakitan, kecacatan dan kematian diperlukan pengendalian stroke. Kegiatan pengendalian stroke meliputi (Kemenkes, 2013):

1) Pelayanan pra stroke : Pelayanan pra stroke adalah kegiatan deteksi dini, penemuan dan monitoring faktor risiko stroke pada individu sehat dan berisiko di masyarakat. Pelayanan pra stroke dilakukan di:
a) Puskesmas
b) Klinik kesehatan
c) Posbindu PTM

2) Pelayanan serangan stroke : Pelayanan serangan stroke dilakukan di:
a) Rumah sakit dipusatkan pada unit stroke atau pojok stroke
b) Rumah sakit khusus
c) Pelayanan paska stroke

3) Pelayanan paska stroke dilakukan di:
a) Rumah sakit
b) Puskesmas
c) Posbindu PTM.

\section{B. Normalisasi}

Pada atribut data cenderung memiliki nilai dengan rentang yang sangat bervariasi dan jenis data masukan berupa data string. Misalnya nilai jangkaun data yang besar akan memiliki pengaruh besar dalam menentukan jarak perhitungan dibandingkan nilai jangkauan data yang kecil. Untuk itu dilakukan proses normalisasi data dengan menggunakan persamaan 1

$$
\text { Rumus Normalisasi Data }=\frac{(\text { Nilai-Nilai min })}{(\text { Nilai max-Nilai min })}
$$

\section{Learning Vector Quantization}

Learning Vector Quantization (LVQ) merupakan salah satu jenis jaringan saraf tiriuan yang berbasis Competitive Learning atau Winner Take All, dimana dari nilai keluaran yang diberikan neuron dalam layer keluaran hanya neuron pemenang (neuron yang mempunyai nilai terkecil) saja yang diperhatikan. Neuron pemenang tersebut yang akan mengalami pembaharuan bobot. Pembaharuan bobot yang dilakukan pada neuron pemenang ini bisa menambah atau mengurangi (Prasetyo, E. 2014).

$$
\begin{aligned}
& \mathrm{d}_{\mathrm{j}}=\sum_{\mathrm{i}=1}^{r}\left(\mathrm{x}_{\mathrm{i}}-\mathrm{w}_{\mathrm{ij}}\right)^{2} \\
& \text { Dimana: } d_{j}=\text { vektor pellatihan } \\
& \mathrm{r} \quad=\text { jumlah fitur yang digunakan } \\
& \mathrm{x}_{\mathrm{i}} \quad=\text { nilai atribut } \mathrm{yang} \text { digunakan } \\
& \mathrm{w}_{\mathrm{ij}}=\text { bobot yang digunakan }
\end{aligned}
$$

Sedangkan untuk pembaharuan bobot pada nuron pemenang menggunakan formula pada persamaan 2.3

$$
\begin{aligned}
& w_{i j}(\text { lama })+\eta\left(x_{i}-w_{i j}(\text { lama })\right), j i k a \omega_{w j}=\omega_{x} \\
& \text { Dimana: } \mathrm{w}_{\mathrm{ij}}=\text { bobot } \\
& \mathrm{x}_{\mathrm{i}}=\text { nilai atribut yang digunakan } \\
& \eta \quad=\quad \text { laju pembelajaran } \\
& \omega_{w j}=\text { kelas target } \\
& \omega_{\mathrm{x}}=\text { kelas neuron }
\end{aligned}
$$$$
w_{i j}(\text { baru })=\left\{\begin{array}{c}
w_{i j}(\text { lama })-\eta\left(x_{i}-w_{i j}(\text { lama })\right), j i k a \omega_{w j} \neq \omega_{x} \quad \ldots(3) \\
\text { tidak ada updater }
\end{array}\right.
$$

LVQ menggunakan konsep kuantisasi perbedaan antara vektor masukan dengan bobot yang dimiliki oleh setiap neuron. LVQ tidak seperti perseptron dimana dalam perseptron setiap kelas diwakili hanya oleh 1 neuron. Dalam LVQ satu kelas dapat diwakili oleh lebih dari 1 neuron. Itulah sebabnya LVQ tidak membutuhkan layer tersembunyi seperti pada Multi-Layer Perceptron (MLP). Operasi yang dilakukan antara vektor dengan bobot tidak menggunakan inner-product, melainkan menggunakan kuantisasi perbedaan euclidean kuadrat. Kuantisasi untuk vektor $\mathrm{x}$ dengan neuron ke-j seperti dinyatakan dalam persamaan 2 (Prasetyo, E. 2014).

Untuk $\omega_{\mathrm{wj}}$ menyatakan label kelas yang diwakili oleh neuron ke-j (neuron pemenang), sedangkan $\omega_{\mathrm{x}}$ adalah label kelas yang sebenarnya diwakili oleh vektor $\mathrm{x}$. Untuk neuron selain neuron pemenang tidak mengalami pembaharuan apa-apa (Prasetyo, E. 2014).

\section{C.1. Proses Pembelajaran $L V Q$}

Pada proses awal pengenalan, vektor input akan mengalami proses pembelajaran yang dilakukan melalui beberapa epoch sampai batas epoch maksimal tercapai. LVQ melakukan pembelajaran pada lapisan kompetitif yang terawasi. Suatu lapisan kompetitif akan secara otomatis belajar untuk mengklasifikasikan vektorvektor input. Kelas-kelas yang didapatkan sebagai hasil dari lapisan kompetitif ini hanya tergantung pada jarak antara vektor input dengan vektor bobot dari masing-masing kelas dan vektor input akan masuk ke dalam kelas yang memiliki jarak terdekat. Algoritma pembelajaran pada LVQ bertujuan mencari nilai bobot yang sesuai untuk mengelompokkan vektor-vektor input ke dalam 
kelas yang sesuai dengan yang telah diinisialisasi pada saat pembentukan jaringan LVQ.

\section{C.2. Algoritma Pelatihan $L V Q$}

Berikut ini adalah langkah-langkah yang perlu dilakukan dalam menerapkan metode LVQ dalam pengolahan data (Prasetyo, E. 2014).

1) Inisialisasi, Tentukan jumlah neuron untuk mengkategorikan semua data latih. Tentukan bobot awal neuron dengan memberikan nilai tengah dari jangkauan nilai setiap fitur. Tentukan laju pembelajaran $(\eta)$. Tentukan fungsi pembelajaran. Tentukan jumlah iterasi.

2) Lakukan langkah 3 sampai 7 hingga mencapai jumlah iterasi atau nilai laju pembelajaran sudah menjadi sangat kecil.

3) Untuk setiap vector latih masukan, lakukan langkah 4 sampai 5.

4) Hitung kuantisasi vector (d) pada semua neuron menggunakan persamaan 2 , kemudian pilih yang paling kecil. Neuron dengan kuantisasi paling kecil menjadi pemenang.

5) Perbaharui bobot neuron pemenang menggunakan persamaan 3 .

6) Perbaharui laju pembelajaran dengan fungsi pembelajaran.

7) Tes kondisi berhenti Jika: (alfa (a) < Mina atau iterasi $>$ Max iterasi) Maka berhenti, Jika tidak : iterasi $=$ iterasi +1 , ulangi langkah ke 4 .

\section{Evaluasi}

Recall adalah ukuran keberhasilan sistem dalam mengenali dokumen pada setiap kategori tanpa melihat ketepatan klasifikasi yang dilakukan. Recall dihitung menggunakan persamaan 4 .

$$
\text { Recall }=\frac{A}{\mathrm{~A}+\mathrm{B}}
$$

Precision adalah ukuran keberhasilan sistem dalam melakukan ketepatan klasifikasi tanpa melihat seberapa banyak dokumen yang berhasil dikenali. Precision dihitung menggunakan persamaan 5 .

$$
\text { Precision }=\frac{A}{\mathrm{~A}+\mathrm{C}}
$$

$F$-measure mewakili pengaruh relatif antara precision dan recall, yang dihitung dengan persamaan berikut. F-measure dihitung menggunakan persamaan 6 .

$$
\text { Fmeasure }=\frac{2 \text { recall } \text {.precision }}{\text { (recall }+ \text { precision })} \text {. }
$$

\section{III.METODE PENELITIAN}

\section{A. Analisa Sistem}

Deteksi dini risiko penyakit stroke termasuk dalam pelayanan pra stroke. Pelayanan pra stroke adalah kegiatan deteksi dini, penemuan dan monitoring faktor risiko stroke pada individu sehat dan berisiko di masyarakat yang dapat dilakukan oleh dokter umum, perawat dan kader kesehatan. Berdasarkan hasil penelitian dikatakan bahwa bila pengendalian stroke dilakukan dengan pendekatan faktor risiko akan mengurangi angka kecacatan sebesar $60-90 \%$, sedangkan penanganan stroke yang tepat pada jam-jam pertama dapat mengurangi angka kecacatan sebesar 30\% (Kemenkes, 2013).

Proses deteksi dini risiko penyakit stroke pasien dimulai dengan pengambilan data faktor-faktor risiko stroke pasien seperti tekanan darah, kadar gula, kolesterol total, Low Density Lipoprotein (LDL), usia, jenis kelamin, asam urat, Blood Urea Nitrogen (BUN) dan kreatinin. Kemudian dokter akan menganalisis data dan mendiagnosa status dini risiko penyakit stroke pasien dalam kategori rendah, sedang dan tinggi. Setelah pasien mengetahui status deteksi dini stroke maka pasien akan diberikan informasi-informasi agar terhindar dari serangan stroke serta meminimalkan faktor-faktor risiko stroke.

Pekerjaan dokter untuk proses diagnosa tidak mudah karena banyaknya faktor risiko yang beragam dan saling memengaruhi, contohnya kolesterol (total dan LDL) dapat menyebabkan penyakit jantung juga dapat berpengaruh terhadapat tekanan darah, jenis kelamin dapat memengaruhi nilai asam urat, asam urat juga dapat memengaruhi tekanan darah dan kadar gula dapat memengaruhi tekanan darah. Oleh karena itu, dibutuhkan suatu sistem pendukung keputusan untuk membantu dokter dalam menentukan tingkat risiko stroke pasien dalam kategori rendah, sedang dan tinggi.

Sistem pendukung keputusan yang dibangun menggunakan metode LVQ. Sistem ini menghasilkan nilai keluaran berupa status risiko penyakit stroke pasien yang akan tergolong kedalam kategori rendah, sedang dan tinggi.

Terdapat beberapa parameter yang dibutuhkan untuk mengetahui status risiko penyakit stroke pasien diantaranya adalah tekanan darah, kadar gula, kolesterol total, Low Density Lipoprotein (LDL), usia, jenis kelamin, asam urat, Blood Urea Nitrogen (BUN) dan kreatinin.

Gambar 1 akan menjelaskan alur sistem pendukung keputusan untuk deteksi dini risiko penyakit stroke menggunakan LVQ.

\section{B. Hasil Analisa}

Sistem pendukung keputusan yang dibangun menggunakan metode LVQ. Sistem ini menghasilkan nilai keluaran berupa status risiko penyakit stroke pasien yang akan tergolong kedalam kategori rendah, sedang dan tinggi.

Terdapat beberapa parameter yang dibutuhkan untuk mengetahui status risiko penyakit stroke pasien diantaranya adalah tekanan darah, kadar gula, kolesterol total, Low Density Lipoprotein (LDL), usia, jenis kelamin, asam urat, Blood Urea Nitrogen (BUN) dan kreatinin. 
Gambar 1 akan menjelaskan alur sistem pendukung keputusan untuk deteksi dini risiko penyakit stroke menggunakan LVQ.

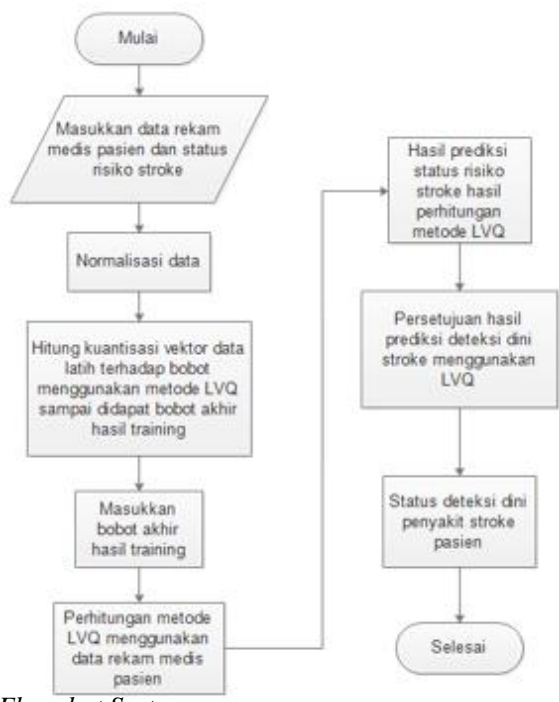

Gambar 1. Flowchat System

\section{Kebutuhan Data}

Data yang digunakan berasal dari data rekam medis pasien dengan diagnosa dokter umum Puskesmas Glagah tahun 2014-2015 sebanyak 128 data pasien.

\section{Proses perhitungan $L V Q$}

Perhitungan Learning Vektor Quantization ini akan menggunakan data latih. Sebelum proses perhitungan data akan dinormalisasi terlebih dahulu. Dari proses pembelajaran ini akan didapat bobot-bobot terbaik dari setiap kelas. Bobot terbaik akan disimpan dan digunkan untuk pengujian sistem. Berikut ini adalah alur diagram dari algoritma LVQ digambarkan pada Gambar 2 :

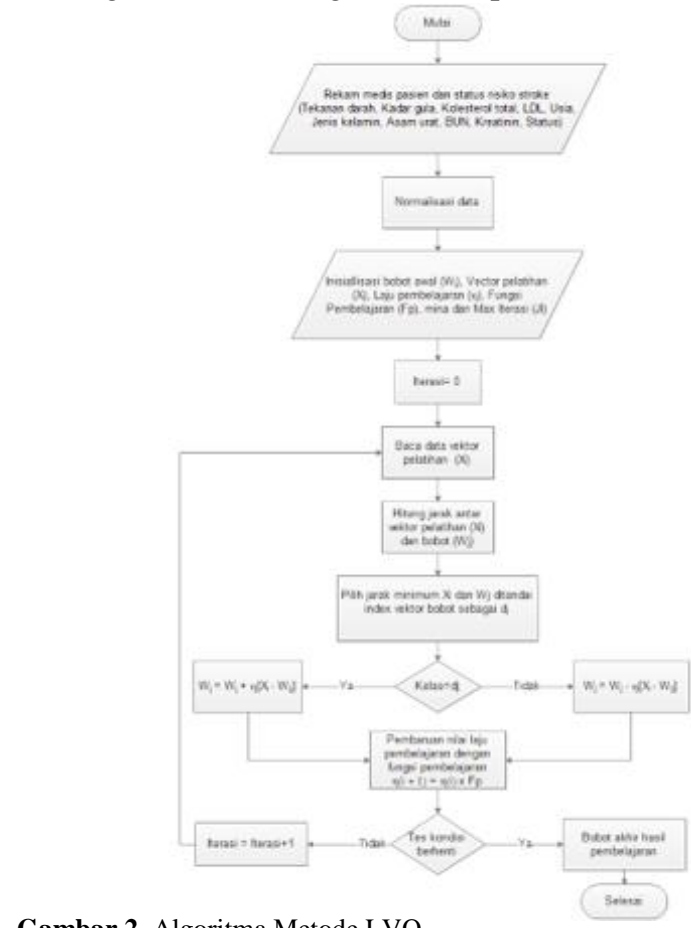

Gambar 2. Algoritma Metode LVQ

\section{E. Diagram Hirarkhi Proses}

Diagram hirarkhi proses merupakan diagram yang menjelaskan secara keseluruhan blok proses yang ada pada sistem. Gambar diagram hirarkhi proses dapat dilihat pada gambar 3:

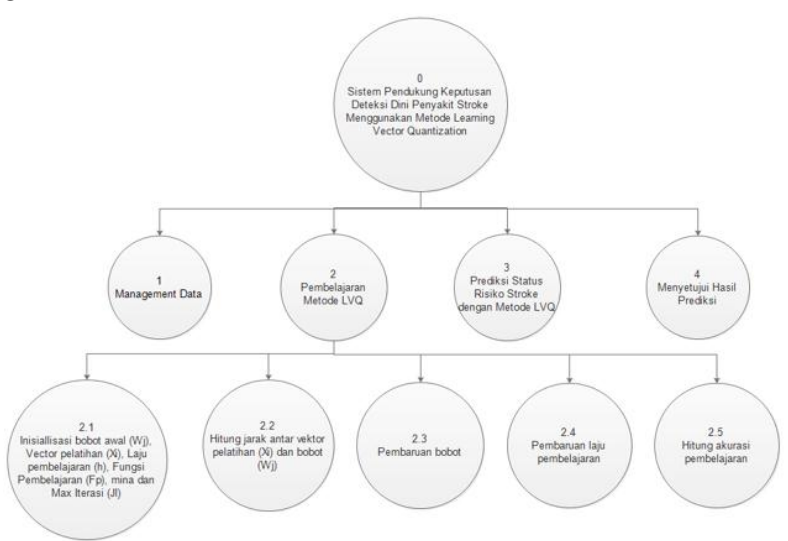

Gambar 3. Diagram Hirarkhi Proses

\section{F. Data Flow Diagram (DFD)}

Data flow diagram adalah alat pembuatan model yang memungkinkan pembuat atau pengembang sistem dapat memahami secara keseluruhan proses aliran data yang ada pada sebuah sistem.

\section{F.1. DFD Level 1}

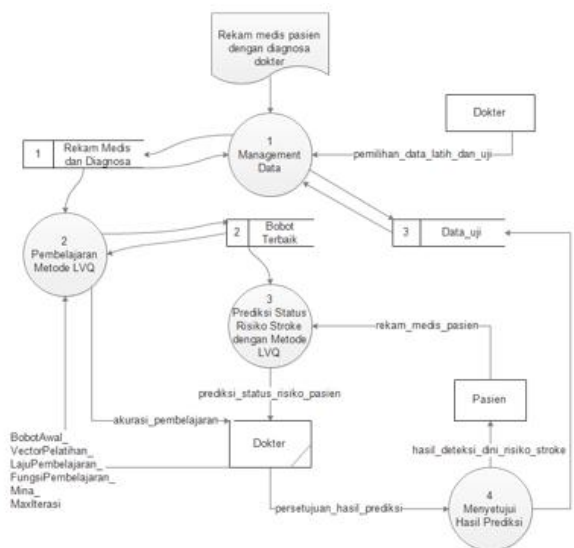

Gambar 4. Diagram DFD Level 1

\section{F.2. DFD Level 2}

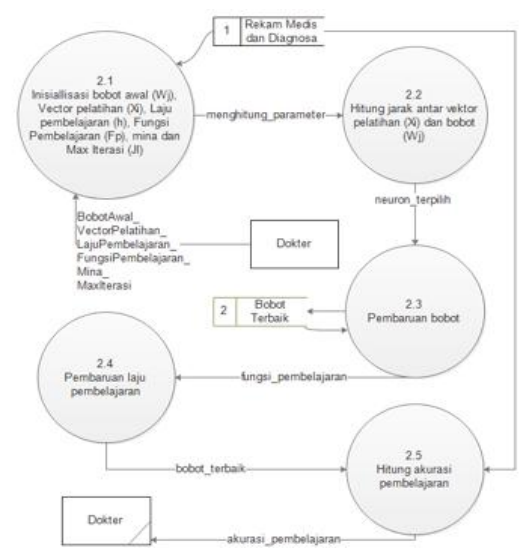

Gambar 5. Diagram DFD Level 2 


\section{HASIL DAN PEMBAHASAN}

Pengujian sistem dilakukan dengan membagi 128 data rekam medis dan diagnosa ke dalam data latih dan data uji. Data latih diambil kurang lebih $70 \%$ dari jumlah data setiap kelas dan data uji kurang lebih 30\% dari jumlah data setiap kelas. Pengujian dilakukan sebanyak 2 kali dengan random data latih dan uji yang berbeda serta 2 kali nilai parameter pembelajaran LVQ yang berbeda.

Pada hasil percobaan pertama dengan menggunakan 90 data latih dan 38 data uji dengan parameter laju pembelajaran 0.04 , fungsi pembelajaran 0.6 , jumlah ietrasi 7 , minimal alfa 0.001 dan bobot yang digunakan 0.5 .

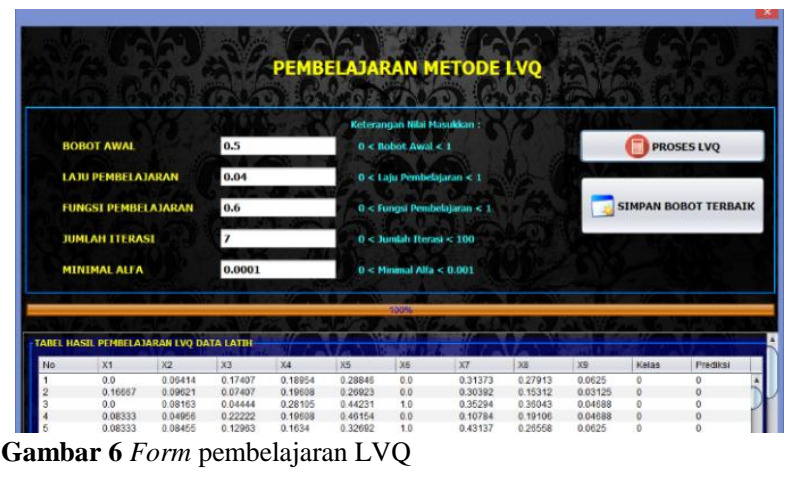

TABEL I. Detail Hasil PRediksi Data Latih PercobaAn PERTAMA

\begin{tabular}{|l|r|r|r|}
\hline \multirow{2}{*}{ Relevan } & \multicolumn{3}{|c|}{ Terbaca } \\
\cline { 2 - 4 } & Rendah & \multicolumn{1}{|c|}{ Sedang } & Tinggi \\
\hline Rendah & 33 & 1 & 0 \\
\hline Sedang & 4 & 14 & 11 \\
\hline Tinggi & 0 & 4 & 23 \\
\hline
\end{tabular}

TABEL II. Evaluasi Hasil Prediksi Data Latih PercobaAn PERTAMA

\begin{tabular}{|c|c|c|c|c|}
\hline Jenis & \multicolumn{3}{|c|}{ Kelas } & \multirow{2}{*}{$\begin{array}{c}\text { Akurasi } \\
\text { Total }\end{array}$} \\
\hline Penilaian & Rendah & Sedang & Tinggi & \\
\hline Precision & $89 \%$ & $74 \%$ & $68 \%$ & \multirow{3}{*}{$78 \%$} \\
\hline Recall & $97 \%$ & $48 \%$ & $85 \%$ & \\
\hline F-Measure & $93 \%$ & $58 \%$ & $75 \%$ & \\
\hline
\end{tabular}

TABEL III. Detail Hasil Prediksi Data Uji PercobaAn PERTAMA

\begin{tabular}{|l|r|r|r|}
\hline \multirow{2}{*}{ Relevan } & \multicolumn{3}{|c|}{ Terbaca } \\
\cline { 2 - 4 } & Rendah & \multicolumn{1}{|c|}{ Sedang } & Tinggi \\
\hline Rendah & 14 & 0 & 0 \\
\hline Sedang & 1 & 7 & 5 \\
\hline Tinggi & 0 & 1 & 10 \\
\hline
\end{tabular}

TABEL IV. EVAluasi Hasil Prediksi Data Uji PeRcobaAn PERTAMA

\begin{tabular}{|l|r|r|r|c|}
\hline \multirow{2}{*}{$\begin{array}{c}\text { Jenis } \\
\text { Penilaian }\end{array}$} & \multicolumn{3}{|c|}{ Kelas } & \multirow{2}{*}{$\begin{array}{c}\text { Akurasi } \\
\text { Total }\end{array}$} \\
\cline { 2 - 4 } Precision & Rendah & Sedang & Tinggi & \multirow{2}{*}{$82 \%$} \\
\hline Recall & $93 \%$ & $88 \%$ & $67 \%$ & \\
\hline F-Measure & $97 \%$ & $54 \%$ & $91 \%$ & $77 \%$ \\
\hline
\end{tabular}

Pada hasil percobaan kedua dengan menggunakan data yang sama seperti percobaan pertama yang berbeda hanya laju pembelajaran diganti 0.005

TABEL V. Detail Hasil PRediksi Data Latih PercobaAn KEDUA

\begin{tabular}{|l|r|r|r|}
\hline \multirow{2}{*}{ Relevan } & \multicolumn{3}{|c|}{ Terbaca } \\
\cline { 2 - 4 } & Rendah & \multicolumn{1}{|c|}{ Sedang } & Tinggi \\
\hline Rendah & 32 & 2 & 0 \\
\hline Sedang & 1 & 20 & 8 \\
\hline Tinggi & 0 & 4 & 23 \\
\hline
\end{tabular}

TABEL VI. Evaluasi Hasil Prediksi Data Latih PercobaAn KEDUA

\begin{tabular}{|l|r|r|r|c|}
\hline \multirow{2}{*}{$\begin{array}{c}\text { Jenis } \\
\text { Penilaian }\end{array}$} & \multicolumn{3}{|c|}{ Kelas } & \multirow{2}{*}{$\begin{array}{c}\text { Akurasi } \\
\text { Total }\end{array}$} \\
\cline { 2 - 4 } & Rendah & Sedang & \multicolumn{1}{c|}{ Tinggi } & \multirow{2}{*}{$83 \%$} \\
\hline Precision & $97 \%$ & $77 \%$ & $74 \%$ & \\
\hline Recall & $94 \%$ & $69 \%$ & $85 \%$ & \multirow{2}{*}{$83 \%$} \\
\hline F-Measure & $96 \%$ & $73 \%$ & $79 \%$ & \\
\hline
\end{tabular}

TABEL VII. Detail hasil Prediksi Data Uji PercobaAn Kedua

\begin{tabular}{|l|r|r|r|}
\hline \multirow{2}{*}{ Relevan } & \multicolumn{3}{|c|}{ Terbaca } \\
\cline { 2 - 4 } & Rendah & Sedang & \multicolumn{1}{l|}{ Tinggi } \\
\hline Rendah & 14 & 0 & 0 \\
\hline Sedang & 0 & 9 & 4 \\
\hline Tinggi & 0 & 3 & 8 \\
\hline
\end{tabular}

TABEL VIII. Evaluasi Hasil Prediksi Data Uji PercobaAn KEDUA

\begin{tabular}{|l|r|r|r|c|}
\hline \multirow{2}{*}{$\begin{array}{c}\text { Jenis } \\
\text { Penilaian }\end{array}$} & \multicolumn{3}{|c|}{ Kelas } & \multirow{2}{*}{$\begin{array}{c}\text { Akurasi } \\
\text { Total }\end{array}$} \\
\cline { 2 - 4 } Precision & Rendah & Sedang & \multicolumn{1}{c|}{ Tinggi } & Tot \\
\hline Recall & $100 \%$ & $75 \%$ & $67 \%$ & \multirow{2}{*}{$82 \%$} \\
\hline F-Measure & $100 \%$ & $69 \%$ & $73 \%$ & \\
\hline
\end{tabular}

Pada hasil percobaan ketiga dengan merandom data lagi didapat 90 data latih dan 38 data uji dengan parameter laju pembelajaran 0.04 , fungsi pembelajaran 0.6, jumlah ietrasi 7 , minimal alfa 0.001 dan bobot yang digunakan 0.5 .

TABEL IX. Detail Hasil Prediksi Data Latih Percobaan KeTIGA

\begin{tabular}{|l|r|r|r|}
\hline \multirow{2}{*}{ Relevan } & \multicolumn{3}{|c|}{ Terbaca } \\
\cline { 2 - 4 } & Rendah & \multicolumn{1}{|c|}{ Sedang } & Tinggi \\
\hline Rendah & 34 & 0 & 0 \\
\hline Sedang & 0 & 19 & 10 \\
\hline Tinggi & 0 & 3 & 24 \\
\hline
\end{tabular}

TABEL X. Evaluasi Hasil Prediksi Data Latih PercobaAn KeTIGA

\begin{tabular}{|l|r|r|r|c|}
\hline \multirow{2}{*}{$\begin{array}{c}\text { Jenis } \\
\text { Penilaian }\end{array}$} & \multicolumn{3}{|c|}{ Kelas } & \multirow{2}{*}{$\begin{array}{c}\text { Akurasi } \\
\text { Total }\end{array}$} \\
\cline { 2 - 4 } & Rendah & Sedang & Tinggi & \multirow{2}{*}{$83 \%$} \\
\hline Precision & $100 \%$ & $86 \%$ & $71 \%$ & \\
\hline Recall & $100 \%$ & $66 \%$ & $89 \%$ & $79 \%$ \\
\hline F-Measure & $100 \%$ & $75 \%$ & $79 \%$ & \\
\hline
\end{tabular}


TABEL XI. Detail hasil Prediksi Data Uji Percobaan Ketiga

\begin{tabular}{|l|r|r|r|}
\hline \multirow{2}{*}{ Relevan } & \multicolumn{3}{|c|}{ Terbaca } \\
\cline { 2 - 4 } & Rendah & Sedang & Tinggi \\
\hline Rendah & 14 & 0 & 0 \\
\hline Sedang & 2 & 7 & 4 \\
\hline Tinggi & 0 & 1 & 8 \\
\hline
\end{tabular}

TABEL XII. Evaluasi Hasil Prediksi Data Uji PercobaAn KETIGA

\begin{tabular}{|l|r|r|r|c|}
\hline \multirow{2}{*}{$\begin{array}{c}\text { Jenis } \\
\text { Penilaian }\end{array}$} & \multicolumn{3}{|c|}{ Kelas } & \multirow{2}{*}{$\begin{array}{c}\text { Akurasi } \\
\text { Total }\end{array}$} \\
\cline { 2 - 4 } Precision & Rendah & Sedang & Tinggi & \multirow{2}{*}{$82 \%$} \\
\hline Recall & $100 \%$ & $88 \%$ & $71 \%$ & \multirow{2}{*}{$81 \%$} \\
\hline F-Measure & $93 \%$ & $67 \%$ & $81 \%$ & \\
\hline
\end{tabular}

Pada hasil percobaan keempat dengan menggunakan data yang sama seperti percobaan ketiga yang bereda hanya laju pembelajaran diganti 0.005

TABEL XIII. Detail Hasil Prediksi Data Latih PercobaAn KEEMPAT

\begin{tabular}{|l|r|r|r|}
\hline \multirow{2}{*}{ Relevan } & \multicolumn{3}{|c|}{ Terbaca } \\
\cline { 2 - 4 } & Rendah & Sedang & \multicolumn{1}{l|}{ Tinggi } \\
\hline Rendah & 33 & 1 & 0 \\
\hline Sedang & 0 & 23 & 6 \\
\hline Tinggi & 0 & 2 & 25 \\
\hline
\end{tabular}

TABEL XIV. Evaluasi Hasil Prediksi Data Latih PercobaAn KEEMPAT

\begin{tabular}{|l|r|r|r|c|}
\hline \multirow{2}{*}{$\begin{array}{c}\text { Jenis } \\
\text { Penilaian }\end{array}$} & \multicolumn{3}{|c|}{ Kelas } & \multirow{2}{*}{$\begin{array}{c}\text { Akurasi } \\
\text { Total }\end{array}$} \\
\cline { 2 - 4 } & Rendah & Sedang & Tinggi & \multirow{2}{*}{$90 \%$} \\
\hline Precision & $100 \%$ & $88 \%$ & $81 \%$ & \\
\hline Recall & $97 \%$ & $79 \%$ & $93 \%$ & \\
\hline F-Measure & $99 \%$ & $84 \%$ & $86 \%$ & \\
\hline
\end{tabular}

TABEL XV. Detail Hasil Prediksi Data Uji PercobaAn KEEMPAT

\begin{tabular}{|l|r|r|r|}
\hline \multirow{2}{*}{ Relevan } & \multicolumn{3}{|c|}{ Terbaca } \\
\cline { 2 - 4 } & Rendah & Sedang & Tinggi \\
\hline Rendah & 13 & 1 & 0 \\
\hline Sedang & 2 & 9 & 2 \\
\hline Tinggi & 0 & 3 & 8 \\
\hline
\end{tabular}

TABEL XVI. Evaluasi Hasil Prediksi Data Uji PercobaAn KEEMPAT

\begin{tabular}{|l|r|r|r|c|}
\hline \multirow{2}{*}{$\begin{array}{c}\text { Jenis } \\
\text { Penilaian }\end{array}$} & \multicolumn{3}{|c|}{ Kelas } & \multirow{2}{*}{$\begin{array}{c}\text { Akurasi } \\
\text { Total }\end{array}$} \\
\cline { 2 - 4 } & Rendah & Sedang & \multicolumn{1}{|c|}{ Tinggi } & \multirow{2}{*}{$79 \%$} \\
\hline Precision & $87 \%$ & $69 \%$ & $80 \%$ & \\
\hline Recall & $93 \%$ & $69 \%$ & $73 \%$ & \\
\hline F-Measure & $90 \%$ & $69 \%$ & $76 \%$ & \\
\hline
\end{tabular}

Hasil pengujian sistem dengan data uji mempunyai tingkat akurasi total yang sama dari percobaan 1 sampai percobaan 3 yaitu $82 \%$, tetapi nilai F-Measure yang bernilai diatas $69 \%$ untuk tiap kelas hanya pada percobaan 2 , sedangkan pada percobaan 4 nilai tingkat akurasi total hanya $79 \%$ padahal tingkat akurasi total pembelajaran data latih mencapai $90 \%$. Dari hasil percobaan yang dilakukan dapat disimpulkan bahwa nilai akurasi total yang sama mempunyai nilai $F$-Measure yang berbeda pada setiap kelas dan hasil akurasi total pembelajaran sistem yang tinggi belum tentu mempunyai nilai pengujian yang bagus, terbukti pada percobaan keempat nilai akurasi pembelajaran mencapai $90 \%$ tetapi nilai pengujian hanya $79 \%$.

\section{PENUTUP}

\section{A. Kesimpulan}

Penelitian ini menghasilkan beberapa kesimpulan sebagai berikut :

1. Algoritma LVQ dapat mengenali pola dan mampu memprediksi status deteksi dini risiko penyakit stroke pasien dengan menggunakan variabel tekanan darah, kadar gula, kolesterol total, Low Density Lipoprotein (LDL), usia, jenis kelamin, asam urat, Blood Urea Nitrogen (BUN) dan kreatinin.

2. Nilai parameter yang digunakan pada algoritma LVQ ini meliputi laju pembelajaran 0.04 atau 0.05 , fungsi pembelajaran 0.6, jumlah ietrasi 7, minimal alfa 0.001 dan bobot yang digunakan 0.5 dalam memprediksi status deteksi dini risiko penyakit stroke pasien dengan nilai akurasi total mencapai $82 \%$.

3. Nilai total akurasi pembelajaran sistem yang tinggi belum tentu mendapat nilai akurasi pengujian sistem yang tinggi juga.

\section{B. Saran}

Saran penulis terhadap Penelitian ini adalah sebagai berikut:

5. Pada penelitian ini, pemilihan data dan nilai parameter LVQ dalam pengujian masih menggunakan trial and error, yaitu melakukan beberapa kali percobaan untuk mendapatkan hasil yang terbaik. Disarankan untuk memilih bobot terbaik dengan mempertimbangkan nilai akurasi total dan $F$-measure setiap kelas yang tinggi serta seimbang.

6. Pada penelitian ini, untuk hasil prediksi sistem kategori status sedang, masih terdistorsi dengan status rendah dan lebih banyak diprediksi dalam kategori status tinggi, diharapkan ada penggunaan metode lain yang dapat mengurangi tingkat distorsi status dini risiko stroke kategori sedang.

\section{DAFTAR PUSTAKA}

[30] Presiden Resmikan Rs Pusat Otak Nasional. Diperoleh 12 Desember 2015 ,

dari http://www.depkes.go.id/article/view/201407200001/presi den-resmikan-rs-pusat-otak-nasional.html

[31] Alfiyanto, E., Dian Eka Ratnawati dan Achmad Ridok. 2014. "Pengklasifikasian Kritik Dan Saran Dengan Menggunakan Metode Fuzzy K-Nearest Neighbour (F$\mathrm{KNN}$ )". Universitas Brawijaya, Malang. [ejournal]. http://filkom.ub.ac.id/doro/archives/detail/DR0009020141 2

[32] Arifianto, Aji Seto, Moechammad Sarosa dan Onny Setyawati. 2014. "Klasifikasi Stroke Berdasarkan Kelainan Patologis dengan Learning Vector Quantization”. Jurnal EECCIS Vol.8, No.2. [ejournal]. 
http://www.jurnaleeccis.ub.ac.id/index.php/eeccis/article/v iew/248

[33] Dharmawan, D.A. 2014. "Deteksi Kanker Serviks Otomatis Berbasis Jaringan Saraf Tiruan LVQ dan DCT". Universitas Gadjah Mada, Yogyakarta. [ejournal].

http://ejnteti.jteti.ugm.ac.id/index.php/JNTETI/article/view File/114/24

[34] Hanafi, H. 2015. Penentuan Klasifikasi Status Gizi Orang Dewasa Dengan Menggunkan Metode Ann Learning Vector Quantization (LVQ). Universitas Muhammadiyah Gresik, Gresik.

[35] Hrp, F.H. 2011. Pendekatan Fuzzy Dalam Pemodelan Sistem Pendukung Keputusan Dengan Analytic Hierarcy Process. Universitas Sumatera Utara, Medan.

[36] Iqbal, M. 2013. Pendekatan Fuzzy Dalam Pemodelan Sistem Pendukung Keputusan Dengan Analytic Hierarcy Process. Universitas Sumatera Utara, Medan.

[37] Kemenkes. 2013. Pedoman Pengendalian Stroke. Kementerian Kesehatan Republik Indonesia.

[38] Nurul, H. Budi,W. 2010. "Prediksi Terjangkitnya Penyakit Jantung Dengan Metode Learning Vector Quantization". Universitas Diponegoro, Semarang. [ejournal].

http://ejournal.undip.ac.id/index.php/media_statistik a/article/download/2522/2313

[39] Prasetyo, E. 2014. Mengolah Data menjadi Informasi Menggunakan Matlab. Yogyakarta: Andi Offset.

[40] Sholeh, A.F. 2012. Aplikasi Pendukung Keputusan Untuk Deteksi Dini Risiko Penyakit Stroke Menggunakan Logika Fuzzy Mamdani :Studi Kasus Di Rs Xyz. Institut Teknologi Sepuluh Nopember, Surabaya.

[41] Valensia, S.A. 2015. "Implementasi Algoritma Fuzzy C-Means Untuk Pembangkitan Aturan Fuzzy Pada Deteksi Dini Risiko Penyakit Stroke". Universitas Brawijaya, Malang. [ejournal].

http://filkom.ub.ac.id/doro/archives/detail/DR000772 $\underline{01506}$

[42] Yastroki. 2011. Sekilas Tentang Stroke. Perhimpunan Dokter Spesialis Syaraf Indonesia dan Yayasan Stroke Indonesia. 